Gandhian Concept of Human Nature

Dr. Anita Dalai

\title{
Gandhian Concept of Human Nature
}

\author{
Dr. Anita Dalai \\ Lect., Dept. of Philosophy, \\ Godabarish Mahavidyalaya, \\ Banapur, Odisha
}

Email:

\begin{abstract}
There has been a persistent attempt to find 'a definition of man' or to point out 'the specific nature of man' in different periods and in different fields. Hobbes gave a pessimistic picture of man whereas Locke and Rousseau gave some pictures. Other ideas about human nature have been discussed by historically important figures are Rene Descartes, Charles Darwin, Karl Marx, and Sigmund Freud. On the whole, they shared any one of these two, that is, man is brutal or bestial. It is important to see which one is acceptable to Gandhi as a political philosopher. Gandhi has a definite conviction about the man and his essential nature. Gandhi's view of human nature can be well articulated from his views on human capabilities and human perfectibility. Moreover, one can very well see that in Gandhian conception of human nature there has been a blending of his metaphysical, theological, ethical, and psychological convictions. In this article, the attempt has been taken to spell out the Gandhian concept of human nature in this direction.
\end{abstract}

Keywords: Human capability and perfectibility, Original goodness

Reference to this paper should be made as follows:

Received: 30.05.2020

Approved: 30.06.2020

Dr. Anita Dalai

GANDHIAN CONCEPT OF HUMAN NATURE

RJPSSs 2020, Vol. XLVI, No. 1, pp. 38-44 Article No.05

Online available at: http://rjpsss.anubooks.com/ https://doi.org/10.31995/ rjpsss.2020v46i01.05 
RJPSSs, Vol. XLVI No.1, June 2020 ISSN: (P)0048-7325 (e) 2454-7026 Impact Factor 7.821 (SJIF)

https://doi.org/10.31995/rjpsss.2020v46i01.05

\section{Inroduction}

\section{Gandhian concept of Human Nature}

In the history of philosophical thoughts, there have been many thinkers who have given thought and attention regarding the nature and status of man. Thinking about human nature is like looking to the core characteristics (feelings, psychology, behaviors) shared by the majority of the people. Since we all have different experiences of the humans in our life, the disputes begin with different views on man. People consider humans in various ways as good or bad, selfish or kind-hearted, rational or brutish, etc. These considerations have special bearings in the activities of man.

The most ancient consideration of man can be traced to the Vedic age. In the Vedic age, human existence was explained through the identity between the individual-self, Atman, and the universal-self, Brahman by the Vedic seers whereas others were sharing some fragmented mystic thoughts about the man. In the intellectual platform, in this tradition, man is treated as amrutasya Putra. Later on, in the different schools of thought, the emphasis on the spiritual aspect of man became quite prominent barring few exceptions. Side by sideman was also treated to be under the influence of ignorance. In the contemporary India, the view that dominates the climate is that man is the spark of the divine. The most spectacular view is shared by Swamy Vivekananda that "The only God to worship is the human soul, in the human body, of course, all animals are temples too, but man is the highest, the Taj Mahal of temples. If I cannot worship in that, no other temple will be of any advantage. "'1

But in the western tradition, the ancient view about man can be traced from the views of the Greek thinkers of the past. Raghavan mentions "in Pythagorean Greece man was regarded as a microcosm of the macrocosm. To understand man one must contemplate the cosmos." 2 They were treating men and animals to be equal. But the only difference is, man is capable of making a plan for the future but this is not possible in the case of animals. In attaching emphasis on man Protagoras said: Man is the measure of all things... It is not a definition that still led the foundation for humanism subsequently. Aristotle has defined man: Man is a rational animal. His emphasis on the reasoning capacity of man is obvious. Aristotle has also said a man to be a social animal.

There has been a persistent attempt to find 'a definition of man' or to point out 'the specific nature of man' in different periods and in different fields. Hobbes gave a nasty picture of a man by saying the man is a selfish and egoistic being. Any 
Gandhian Concept of Human Nature

Dr. Anita Dalai

hedonist would have said man is a pleasure-seeking animal. Locke has said a man is naturally harmless, self-improving, and inherently good. Hegel opined man to be 'political' as well as 'metaphysical'. Other ideas about human nature have been discussed by historically important figures are Rene Descartes, Charles Darwin, Karl Marx, and Sigmund Freud. Even though Marxian and Cartesian approaches are materialistic but they differ greatly in forming the conception of human nature. Raghavan points out that "Marx's failure to formulate a clear conception of human nature makes it easier for us to regard him as a crusader and powerful propagandist rather than as a political thinker, in a strict sense." ${ }^{3}$ However, Karl Marx believed that human nature is revealed through the natural progress of history. He believed that history's natural progress could lead humans to true freedom as they recognized the culture and social factors that alienated them from their natural identity. In this perspective, his approach is found to be Darwinian. Marx seems to have considered that humans are characterized by their species traits. He was against the view of divine spark or the spiritual aspect. Descartes started describing a man as a thinking spirit but emphasized on mind-body dualism. 'He was later criticized by Gilbert Ryle, who like Aristotle, could not completely separate human mental processes from physical ones.'

Darwin and Darwinians consider humans to be as good as animals sharing some special features with time and those human characteristics are the product of nature and developed through circumstances. Freud and Freudians, try to present the picture of man attaching emphasis on the psychological aspect of a man mostly basing on their analysis of the urges and impulses. Some psychologists try to reduce man to be the combination of impulses, desires, and emotions. It was Hegel who has considered that man is both metaphysical as well as political. Locke and Mill have pointed out that man's political and economic involvements are obligatory and helpful to society. This is how we see that there has been a persistent attempt to arrive at a correct understanding of man. Raghavan rightly points out that "The choice between an optimistic conception (from Plato to Kant) and a pessimistic view (from St. Augustine to Hobbes) of human nature is logically independent of the choice between an open and a closed view of human nature, or again, of the choice between the acceptance and rejection of the perfectibility of man, or finally, the degree of power and autonomy that is granted to man concerning Nature (or God) and his material and social involvement." 4 The alternatives given by the political philosophers of the past Three distinguished political philosophers, namely, Hobbes, Locke, and Rousseau have given three different views on human nature and those seem to cater to the three possible alternatives present before us from 
RJPSSs, Vol. XLVI No.1, June 2020 ISSN: (P)0048-7325 (e) 2454-7026 Impact Factor 7.821 (SJIF)

https://doi.org/10.31995/rjpsss.2020v46i01.05

the perspective of political philosophy.

(i)

According to Hobbes, man is basically brutish, nasty. Man is selfish, egoistic, and guided by emotions. It is natural to him that one human is against another human.

(ii) According to Locke, human nature is inherently good. Man is naturally harmless and man is self-improving. Men are moved by sympathy, love, tenderness for which he is helpful for the mankind and society.

(iii) According to Rousseau, men were non-social only in the primitive stage. They were neither egoist nor altruist. They were in the premortal state. The picture of man changed after the formation of the society, which is the product of his inherent nature. So for him, man is not naturally bad, but society corrupts man and makes him worse

Now clubbing the two later views in one category, we have before us this contrary option: Man is brutal or bestial. It is important to see which one is acceptable to Gandhi as a political philosopher. Gandhi has a definite conviction about the man and his essential nature. He would prefer to say that these pictures of man are superficial and partial because they do not emphasize the basic truth about man. Gandhi's view of human nature can be well articulated from his views on human capabilities and human perfectibility. Let us have a look at some of the views of Gandhi on human capabilities and human perfectibility.

\section{Gandhi on human capabilities and perfectibility}

He considers that in tune with the progress in the evolutionary process the spiritual aspect in men becomes more and more prominent. In the Harijan, he has mentioned all are originally brutes. There has been a slow process of evolution from brutality towards goodness. For him, evolution stands for proceeding towards spirituality from the state of physicality aiming at the complete realization of the spirituality or the divinity. Men have come to this earth in the image of God. Men possess the qualities like free-will, reason, consign, and love. All these are symbols of the divine spark in him. According to Gandhi since, the essence of man is his soul which is the divine spark it cannot be bad. Its essence is good. Gandhi believes in the absolute oneness with the God. For him, the spiritual nature of men is the true nature of men. In human nature, spirituality is more reflected than his bodily aspect.

Gandhi has believed in the doctrine of karma. Man is the maker of his own destiny. He has the freedom of choice for the type of life he wants to live in. As a social being man is neither brute nor God but the specialty with him is that he uniquely 
possesses the power of choice that can either increase brutalization in his nature or the awareness of his innate divinity. He considers that man can find God, in the creations of God. This can be possible by developing the attitude of service to mankind and nature. He has written, "I am a part and parcel of the whole and I cannot find Him apart from the rest humanity." Thus, Gandhi was a practical idealist. He considers man to share in him both goodness and badness. The downward instinct is easy, especially when it is available in beautiful garb. After birth, the early life of man is his physical life. Gradually he proceeds towards spirituality. He passes from brutality to non-brutality. "We are thus born with brute strength but we are born men to realize God who dwells in us. That indeed is the privilege of man and it distinguishes him from the brute creature." 5

In his autobiography, he has said a man is a superior species because he has the capability of 'self-restrained'. Men alone can follow the path of renunciation for which he can be distinguished from all other animals. Men alone can think of the betterment of their fellow beings. Man is always a self-improving animal. He is capable of developing further. He's capable of examining himself. He can cultivate love, fellow- beings, emotional attachment, etc. Men can be good by using their free will. He has the capacity of evaluating himself. Men can practice non-violence and satyagraha. Man is morally accountable. Men are incapable of swallowing injustice calmly. He tends to proceed towards perfection.

\section{To sum up}

Men were originally brutes. Due to his innate nature, there is a slow process of evolution towards goodness.

Man is the man because he is capable of self-restraint.

Man is self-improving.

He is morally accountable.

He is incapable of digesting injustice.

Man is different from animals as he can follow the path of renunciation.

Violence immediately catches mind. If goodness can be awakened he cannot continue with violence.

Spiritual nature of man is the true nature of man.

Man has come to this earth in the image of God. He has qualities like freewill, reason, conscience, and love.

Man sins become corrupt to satisfy his body.

Man sometimes exhibits his badness circumstantially. 
A critical look on the Gandhian notion of man that man is basically nonviolent, good, and can undergo moral transformations easily proves that rationality dominates in man. It shows that the Gandhian view appears to be contrary to the view of many modern psychologists who hold that human behaviors are guided by their instincts and biological urges, not by rationality. Critics have pointed out that Gandhi has given an optimistic view about man, which is neither realistic nor possible. To this Gandhi's reply can be since every man is the mixture of good and evil. The bad aspect is mostly due to his body and flesh. Man sins to satisfy his body that may be a very negligible aspect of man. Here a question can be raised that, if the man is basically good then how riots, wars, mass-killing, various evils could occur in society? In this context Gandhi's reply would be in such cases the unjust system is more responsible than a man. Man undergoes in a system. Man becomes corrupted if the system goes corrupted. Man becomes revolutionary when injustice dawn upon him. His animality and aggressiveness nature comes out. Moreover, for him violence immediately catches mind. If goodness can be awakened he cannot continue with violence. Spiritual nature of man is the true nature of man. Hence for him, human nature is basically good though he shares both goodness and badness. Gandhi's emphasis was this goodness of man to which he considers the 'original goodness'.

Epilogue

Gandhi was an atheist. He has mentioned in young India, that he believes in the philosophy of Advaita. He was a Vaisnava and also a believer of Sri Rama as his personal God. Despite all these, all his messages were relevant and meaningful in the human context, this is hardly disagreeable. His notion of man is neither materialistic nor completely spiritualistic. For him, man is the combination of spiritual as well as material. No man is permanently good and bad. Human life is a series of compromises. As a practical idealist, he wanted that there must be an effort to establish well. At the initial stage, the physical aspect of man is exposed to a great extent and he follows the laws of nature. There is a gradual development of spirituality in man with the awareness of good and bad, truth and falsehood, etc. He engages himself in gaining worldly good, when the bodily aspects dominate him. When the spiritual aspect starts dominating he detaches himself from selfish brutish, activities and engages himself in practicing human virtues.

One can very well see that in Gandhian conception of human nature there has been a blending of his metaphysical, theological, ethical, and psychological convictions. So far as his metaphysical conviction is concerned soul as the essence of man and his adherence to monism is found as the key factor. In the theological perspective, God to be the architect of man in His model and the presence of the 
divine qualities in man, has been focused. In the psychological aspect, he considers that man chooses its personality type being guided by his nature. Above all the moral influence on man happens to be the most important consideration in respect of the human nature is quite obvious. It is because if Gandhi would have defined man he would have said: Man is a moral animal or moral being. No other species other than a man can be moral.

\section{References}

1 Swami Vivekananda, Complete works, p.321.

2 Iyer, Raghavan N., The Moral and Political Thought of Mahatma

Gandhi, Oxford University Press, New Delhi, 2012, p.89.

$3 \quad$ Ibid, $\mathbf{p . 8 8}$

$4 \quad$ Ibid, pp. 88-89

5 Mahatmya Gandhi, Harjana, April,1938. 